\title{
The Effectiveness of Extrinsic Cues on Different Consumer Segments: The Case of Wine Awards
}

\author{
Rosemarie Neuninger ${ }^{1}$, Damien Mather ${ }^{1, *}$, Tara Duncan ${ }^{2}$ \\ ${ }^{1}$ Department of Marketing, University of Otago, New Zealand \\ ${ }^{2}$ Department of Tourism, University of Otago, New Zealand
}

Copyright $\mathrm{O} 2016$ by authors, all rights reserved. Authors agree that this article remains permanently open access under the terms of the Creative Commons Attribution License 4.0 International License

\begin{abstract}
We investigated the effectiveness of awards on wine labels for different consumer segments. Four award configurations were tested: a well-known award, multiple awards, a fictitious award (an award without consumer trust) and no award. Participants tasted eight wine samples (four without and four with extrinsic cues - award configurations). Samples were rated for liking, likelihood to buy and price willing to pay. Low-involvement consumers' perceived liking and price willing to pay were improved by multiple awards compared to high-involvement consumers. Trust in awards increased the price consumers were willing to pay for wine with an award. For high-involvement consumers who distrusted awards, multiple wine awards and fictitious awards negatively influenced perceived liking, likelihood to buy and price willing to pay. This is the first study to measure the combined influence of wine awards and sensory perceptions of wine on perceived liking, likelihood to buy and price willing to pay.
\end{abstract}

Keywords Wine Awards, Sensory Perceptions, Trust/Distrust, Involvement, Generalised Linear Model

\section{Introduction}

Wine shows or competitions exist in most wine producing countries and wine producers enter competitions in the hope of receiving an award that can be displayed on their products. Many producers believe that receiving an award will (a) improve awareness of their wines, (b) establish a positive brand image, (c) gain credibility for their brand, and importantly, (e) increase their overall number of sales (1). In New Zealand, the main competitions are Air New Zealand wine awards, New Zealand Wine Society wine show, Royal Easter wine show, Liquorland Top 100, International Chardonnay Challenge, Hawke's Bay A\&P Mercedes-Benz wine show (2), and Cuisine magazine.

During a typical wine competition, each wine's organoleptic properties (e.g., taste, mouth feel, sight, smell, balance and typicality) are compared and evaluated by a group of judges without any label or brand cues. In reality, entering a competition may not be always profitable, as the winery will have to pay to enter trading competitions like in New Zealand where there is an entry fee (3). Furthermore, Pendock (4) made a similar observation and pointed out that "they all charge hefty entrance fees of around R1000 a bottle and are nice little earners for the entrepreneurs involved. Sponsors are in place so it's not clear why producers have to pay too, unless it's to boost profits". This is showing that entering competitions can be expensive and if no medal is won, the winery will not reap any benefit from the investment. Among others Charters (5, p. 219) argued, 'the very best producer will rarely enter their wines in a competition' as a low rating will result in potential damage to their wine's reputation. This sentiment was shared by Pendock (6) who argued that "many wines that are viewed as extraordinarily good at some competitions are viewed as below average at others." Meaning that the winery will potentially end up with a different medal status from two different competitions and lose their credibility. It is for these reasons, that wine producers must carefully consider if they participate in a wine show or not.

Winegrowers will also have to decide which competitions to enter. Some wine competitions are more prestigious than others and the results may purely reflect the taste of the judges. Charter (5) suggested that the quality of the show is determined by who the judges are, how they judge, and the organisation of the show. For instance, in New Zealand, the panel generally consists of a mixture of highly respected international wine judges as well as national senior and associate judges, who may be professional winemakers, wine writers, or sommeliers (7). This decision to participate is further complicated by the binding nature of competition entry agreements, which enforce the display of an award on a wine label once earned for that year's vintage.

The format of the wine competition has an important effect on the value of its outcome. The organisation of the show must guarantee that all wines are tasted 'blind' and in an appropriate judging environment (5). However, when 
wines are tasted 'blind' the results reflect the pure taste perceptions of the judge. Schiefer and Fischer (8, p. 337) suggested that experts' ratings are based on "whether a wine is free of faults and typical for its variety, origin and vintage". During a competition some judges might rate the wine on how it tastes now, and others on how it will taste in the future (9). Another issue is the large amount of wine that is being judged in one competition - often up to 200 different wines which may affect the actual aroma of the wine (5, p. 998). Variations in award process consistency and reliability logically lead to issues of award trust and distrust.

In addition, one can also observe an increasing amount of wine with misleading and/or multiple awards. Orth and Krška (1) concluded that the increasing number of wine awards in recent times dilutes the effect of each award on the consumer. Herbst and von Arnim (10, p. 92) pointed out that "cheating [by adding a pseudo-award to a wine bottle] seems to be worthwhile for producers and:

the perceptions that are derived from the mere appearance of the bottle and label are very powerful in influencing decision-making. It appears that consumers frequently pay no particular attention to the information contained on the medal sticker, but simply respond to the cue of a round golden shape."

On the other hand, a pioneer of the Central Otago wine industry (one of the leading wine-producing areas in New Zealand) and founder of the Gibbston Valley Wines - one of Central Otago's prime wineries - has written:

"Medals no longer hold the glamour they once did for me. At best they give consumers a glimpse of how a panel of three judges, in an assessment lasting approximately one minute, rated a particular wine against possibly several hundred others of the same variety or style. If the wine is lucky enough to score a silver medal or better, producers can blow the trumpet and tell the world about it, thereby influencing many who rely on others to decide for them what is good and what isn't." (11, p. 178).

The above scenarios illustrate that there is an increasing distrust in wine awards as a marketing tool. If this current trend continuous, we predict that wine awards will slowly and quietly not only loose all positive value but acquire a net negative value in wine markets. To avoid this marketing tragedy there is a need to review the credibility and effectiveness of wine awards on different consumer segments.

\subsection{The Importance of Wine Awards in Relation to Other Extrinsic Cues}

"Wine awards are an extrinsic cue, often in the form of a round sticker on a wine bottle that serves to indicate to the consumer that experts have judged the wine on its intrinsic characteristics to determine the overall quality" $(12$, p. 15$)$. Previous studies involving wine awards measured the relative importance of wine awards in relation to other extrinsic cues such as promotional displays, label colour, style, price band, variety, vintage, region, country of origin, food matching recommendations, alcohol content and brands. These studies applied different methods including surveys, revealed and stated preference choice studies and varied in the scope of effects investigated. Mueller et al. (13) in particular argues that studies employing cognitive response tasks produce different findings to those employing more subconscious methods and explains why these differences exist in more detail. Mather et al. (14) show and explain why revealed (actual) and stated (hypothetical) responses to choice experiments can substantially differ. These differences perhaps explain in part why they generally come to different conclusions about the relative importance of wine awards. For example, Lockshin et al. (15) found that awards and brands were more important than region and price for consumers when choosing a wine. Johnson and Bastian (16) found that those with low wine expertise rated awards or medals eighth in importance out of twenty cues. Conversely, wine awards did not affect the purchase decisions of participants in the higher expertise groups. Later, Lockshin et al. (17) identified brand, price and medals (awards) to be the key drivers for wine choice, whereas closure (i.e. cork or screw cap), label colour and label style were less important for consumers. Herbst and von Arnim (10) concluded that consumers perceived wine awards as relatively unimportant compared to other extrinsic cues such as variety, vintage, producer, production method, packaging, place of origin and price. Jaeger et al. (18) were relatively ambitious in scope, testing thirteen choice criteria accessible to consumers when purchasing wine from retail locations. The most important purchase factor they found was 'Tasted the wine previously', regardless of segment membership, the most important purchase factor. Medal/award was the fourth most important factors influencing consumers' wine choice. Chrysochou et al. (19) also used these same thirteen attributes as Jaeger et al. (18) to explore wine preferences between Generation $\mathrm{Y}$ and older cohorts in the USA. 'Promotional display in-store' was rated number one and 'Medal/award' was rated number eight. Corsi et al. (20) found that awards were the second more important attribute behind grape varietals and ahead of the price listed on a menu in a restaurant setting. Chrea et al. (21) investigated the influence of region, grape, price, vintage and awards using a real commercial wine sample and showed consistent results. Regardless of the methods used, scope adopted and conclusions are drawn about the relative importance of wine awards, all of this research cited above still somehow confirms the importance of wine awards.

\subsection{The Use of Wine Awards by Consumers with Different Levels of Involvement and Interest towards Wine}

Consumers' level of involvement has long been an important topic of interest in marketing research. During the decision-making process, consumers unconsciously adopt 
either a high or a low level of involvement. Involvement, as defined by Zaichkowsky (22, p. 342) is "a person's perceived relevance of the object based in inherent needs, values, and interests". Charters and Pettigrew (23, p. 998) suggested "that a wine drinker's consumption behaviour varies substantially with involvement level, creating complex interactions with store usage, consumption situation, age, income and cues (critically, variety and region of origin)". Wine awards, as extrinsic cues have been found to have differing influences on different wine consumer groups. For instance, Lockshin et al. (15) showed that gold awards influenced both high-involvement consumers and low-involvement consumers although they had the highest effect for low-involvement consumers at lower and middle price points. Bronze medals, however, had little effect on any consumer group. Herbst and von Arnim (10) argued that the sophisticated wine consumer is less interested in awards and their attitudes towards wine awards are therefore more negative. In contrast, less informed consumers are more likely to use wine awards as guidance and are therefore more open-minded towards the concept of wine awards. More recently a synthesis of wine consumers' segmentation studies suggests a five-way segmentation. Contributions from Lockshin and Spawton (24); Lockshin and Hall (25) identify three of the five segments (high, medium and low involvement) were combined with contributions from Charters (5); Keown and Casey (26); Spawton (27) separately identifying the "new wine drinkers" segment. Finally, Neuninger (12) further identified "Experts" as a fifth wine consumer segment. Thus, Neuninger (12) used focus groups and segmented consumers according to their interest in wine into 1) Expert consumers (ECs), 2) High involvement consumers (HICs), 3) Medium involvement consumers (MICs), 4) Low-involvement consumers (LICs) and 5) New Wine Drinkers (NWDs). The results show that ECs, HICs as well as MICs were selective about which awards they used; for example, the 'Cuisine award' (from a consumer magazine), was considered trustworthy. Table 1 shows the interest profiles of the different involvement segments around wine awards that were identified using qualitative research methods.

Thus, we are led to inquire: what is the impact of consumer involvement, wine award level, the number of wine awards, general wine award trust level, and general wine award distrust level affect consumer preference for, perceived value of, and consumption behaviour surrounding wine. In this study, we will conduct a blind tasting experiment followed by an informed tasting with the same participants to measure consumers' overall liking, likelihood to buy, and willingness to pay.

Table 1. Interest profiles of different wine consumer segments around wine awards.

Interest profiles of different wine consumer segments around wine awards.

ECs "are wine consumers who have institutional experience with wine and/or have received training in this product category" Neuninger (12). This group is mainly influenced by wine writers (e.g., Jancis Robinson, Robert Parker, and Charmian Smith) and they purchase frequently in bulk via the internet, wineries, or wine speciality stores. However, they are interested in prestigious wine competitions, attentive to trophy winners (the highest wine award category) and try sometimes wine with a gold medal.

HICs are interested in wine and they appear not to be attracted by awards. They are interested in trying different types of wine and they are most likely to be influenced by the media, salespeople, friends and hospitality providers.

MICs are less interested in wine than HICs and more interested in wine than LICs. They are likely to use awards when choosing unfamiliar wine, principally as a means of quality control (e.g., when selecting wine as a gift). They often seek the advice from salespeoples in specialty wine stores and use well-known awards.

LICs are primarily interested in the price of the wine. A gold medal influences them when under time pressure and when the price of the wine is reduced. Purchase their wine in the supermarket and they pay attention to fancy labels.

NWDs are young wine consumers who are influenced by parents or peers, have not established preferences and often use price as the main determinant of their purchase. This group is not interested in wine competitions. However, they sometimes use gold medals because they found them pretty and shiny. 


\section{Materials and Methods}

Before the main study, the experimental procedures were pilot tested with a separate small sample of participants $(n=10)$, and were evaluated and fine-tuned before implementation. It was found that it was important to direct participants when tasting the second group of wine (informed condition) verbally, as well as with written information, to note the award on the bottle so that it is consistent with the level of attention in a real purchase situation $(12,28)$, thus enhancing the environmental validity of the research design. Also, it was necessary to change the wording from 'price' to 'price per bottle' when participants were asked how much they were willing to pay, since the order-size was shown to be unclear in the pre-test. The learnings with the pilot study did not preclude the pooling of their response data with the main study as described below.

\subsection{Participants}

Table 2. Socio-demographic details of participants (excluding $n=10$ from the pilot study)

\begin{tabular}{|c|c|}
\hline \multicolumn{2}{|l|}{ Samples characteristics } \\
\hline Characteristics & $\begin{array}{c}\text { Percentages } \\
\quad(n=67)\end{array}$ \\
\hline \multicolumn{2}{|l|}{ Gender } \\
\hline Male & 50.7 \\
\hline Female & 49.3 \\
\hline \multicolumn{2}{|l|}{ Age } \\
\hline 18-24 years old & 88.1 \\
\hline $25-29$ years old & 6.0 \\
\hline $30-49$ years old & 4.5 \\
\hline Over 65 years old & 1.5 \\
\hline \multicolumn{2}{|l|}{ Educational attainment } \\
\hline High School Level Certificates & 50.7 \\
\hline $\begin{array}{c}\text { Tertiary Education Level Certificate/Diploma (non } \\
\text { University) }\end{array}$ & 7.5 \\
\hline Bachelors Degree & 40.3 \\
\hline University Level Postgraduate qualifications & 1.5 \\
\hline \multicolumn{2}{|l|}{ Annual household income before tax (NZD) } \\
\hline Less than $\$ 25,000$ & 49.3 \\
\hline$\$ 25,001-\$ 40,000$ & 9.0 \\
\hline$\$ 40,001-\$ 50,000$ & 11.9 \\
\hline$\$ 50,001-\$ 60,000$ & 3.0 \\
\hline$\$ 60,001-\$ 70,000$ & 1.5 \\
\hline$\$ 70,001-\$ 100,000$ & 9.0 \\
\hline$\$ 100,001-\$ 120,00$ & 3.0 \\
\hline$\$ 120,001-\$ 150,00$ & 1.5 \\
\hline More than $\$ 170,000$ & 9.0 \\
\hline
\end{tabular}

A blind versus informed condition experiment was conducted in Dunedin, in the South Island of New Zealand in January 2013. The ethics committee from the authors' institution approved this study (Reference number 11/188).
The entry criterion included being over the age of 18 , having consumed wine in the past and absence of allergies or intolerance to wine. In addition to the responses from participants from the pilot study $(n=10)$ we added a convenience sample of the New Zealand wine drinking population $(n=67)(49.3 \%$ female and $50.7 \%$ male) mainly of age 18-24 (81.1\%) who attended a Summer School paper, 'Introduction to Wine Business' at the authors' institution, who took part in the experiment. The paper is for 'anyone' and is especially suited for students who would like to increase their knowledge about wine and wine business. Commonly, students come from many disciplines, including tourism and are more widely representative of the general population (see Table 2 for socio-demographic details of the participants of this study). No credit was awarded to the students for participation. Thus, we obtained response data from 77 participants in total from the pilot study and the main study.

For the experiment, twenty-eight bottles two different types (wine I and wine II) of red wine (fourteen bottles of wine I and fourteen bottles wine II) from New Zealand (Central Otago Pinot Noir) were used. On the day of the experiment, the wine was served into eight wine glasses per participant (a total of 536 glasses, fifteen milliliters of wine per sample, a total of $120 \mathrm{ml}$ wine per session) each topped with a fitting cover of a Petri dish (a shallow circular plastic dish with a loose-fitting cover) to maintain the wine's flavour for as long as possible. Participants completed the experiment in four different sections: firstly, the information and consent sheet (Part 1), followed by the response booklet (Part 2 - blind condition scores, and Part 3 - informed condition scores), and questionnaire (Part 4 socio-demographic details, and general questions about experiences with wine awards). During the uninformed condition, participants tasted four glasses of wine with no addition information such as images of the wine bottles, whose wine they may have tasted. This uninformed condition corresponds to the 'no award' treatment level in the experimental design. Conversely, during the following informed condition, participants were shown one picture containing four numbered wine bottles each with a different hypothetical label and award configuration. One of the four awards was a fictitious award. The use of hypothetical labels, including awards in wine marketing research, has some precedence in the literature (see for example Lockshin et al. (17) Each wine they tasted, during the informed condition was differentiated by a letter corresponding to one of the labelled wine bottles in the image shown. This informed condition corresponds with four of the five treatment levels in the experiment design, the fifth level being the 'no award' treatment level as discussed above. The wine bottles in the informed condition image displayed the following four configurations: 1) no award (29), 2) Cuisine award, 3) Black Cherry Best Wine Award (fictitious award), and 4) Multiple awards (Bragato; New Zealand International Wine Show; International Wine Competition). Part 2 and 3 of the response booklet recorded judgments on how much the 
participants liked or disliked each wine (under both blind and informed conditions), how likely they would be to buy the wine, and how much they were willing to pay for a bottle of the tested wine. The first two questions (in Part 2 - blind condition scores, and in Part 3 - informed condition scores) were answered on five-point Likert scales, which are widely used and accepted measurement scales (30-32). The response to the third question was responded to by writing in a dollar value. In Part 4, the present study included questions previously used by Orth and Krška (1) in order to measure participants' recognition of wine awards for quality assurance. Responses were recorded on a five-point scale semantically anchored and detached with bipolar anchors ( $1=$ Strongly-agree and $5=$ Strongly-disagree $)$ and a center anchor phrase. Some questions were reverse-anchored.

\subsection{Procedure}

The purpose of presenting the samples in a different order was to average out any taste-related ordering effects (33). The two different wines were used to give participants the impression that each wine sample they tasted was a different wine to the previous sample, without increasing overall experiment costs beyond the budget for the study. Participants were allowed up to one and a half hours to complete their responses. Each participant evaluated the appearance, odour, taste, flavour, texture/mouth-feel and aftertaste of the eight samples. Based on the evaluation, participants were asked to indicate how much they liked the wine, their likelihood to buy and the amount that they were willing to pay. Participants provided their socio-demographic details; answered questions related to their experiences with wine awards and provided information about their general awareness and use of wine awards.

In order to show effectiveness of awards on wine labels for different consumer segments five hypotheses were formulated. The hypotheses are based on the findings of the study conducted by Neuninger (12), as well as from findings of the literature review.

A study by Lockshin et al. (15) shows that gold awards had a high effect on LICs in particular. In addition to their study, we assume that multiple (real gold) awards will also have the same effect on LICs. This motivates hypothesis 1 :

$\mathrm{H}_{1}$ : For wines with multiple (real gold) awards, LICs are more likely to:

a) buy a wine.

b) like a wine.

c) pay more for a wine.

The next hypothesis seems intuitively obvious but must be verified experimentally.

$\mathrm{H}_{2}$ : Consumers who trust awards are less likely to:

a) buy a wine with no award.

b) like a wine with no award.

c) pay more for a wine with no award.

d) Based on the findings by Neuninger $(12$, p. 89), consumers who are highly involved with wine only trust a few prestigious awards. This motivates hypothesis 3 :

Consumers who distrust awards and who are highly involved with wine are less likely to:

a) buy a wine with a fake award.

b) like a wine with a fake award.

c) pay more for a wine with a fake award.

This same findings also motivates hypothesis 4 :

$\mathrm{H}_{4}$ : Consumers who distrust awards and who are highly involved with wine are less likely to:

a) buy a wine with multiple awards.

b) like a wine with multiple awards.

c) pay more for a wine with multiple awards.

The sensory experiment drew participants from those taking the 'Introduction to Wine Business' paper at the authors' institution, which is a paper for a 'non-typical' student demographic. It is therefore expected that the socio-demographic status of our experiment will place participants mainly (but not exclusively) into the NWDs consumer segment identified by Neuninger (12) and Spawton (27). Motivated by the results of the study by Neuninger (12), it is therefore expected that this consumer segment will be not well informed about the topic of wine awards, particularly compared to the knowledge of HICs and ECs.

$\mathrm{H}_{5}$ : NWDs have less interest in wine awards than other wine drinking segments.

When testing all hypotheses (except $\mathrm{H}_{5}$ ) the informed condition with no award will control for the effect of the other extrinsic characteristics visible to participants, i.e., the shape of the bottle and the content of the label. It is expected that this effect will be negligible.

\subsection{Data Collection}

A week before the experiment took place all participants were sent an email containing the information sheet with the procedure of the study and consent form to read before the experiment. This information was also provided on the day of the experiment. This information was provided twice to ensure that participants were informed about the procedures of the experiment (e.g., that the experiment session was going to be held in the afternoon and during class time, the total amount of alcohol that was going to be served, and drink and driving restrictions). In addition, it was explained that no alcohol was to be swallowed during testing. As an incentive for taking part, participants had the opportunity to enter a draw to win a supermarket grocery voucher, valued at NZ\$50.

On the day of the experiment and prior to entering the experiment room, participants were split into two groups (on arrival, participants were asked to line up, and alternate participants were assigned to different groups). The two groups, as outlined in the design, received the same wine samples (a total of eight glasses) but in different orders. To minimize psychological and physiological biases affecting 
human responses, participants were asked to sit at individual tables (34). Each participant's table contained a consent form, information sheet, questionnaire, eight wine glasses, water, and crackers. Prior to beginning the experiment, each participant was asked to read the information sheet and to sign the consent form.

After collecting all consent forms the researcher explained the procedures used for the purpose of the experiment. Typical wine tasting procedures used in the wine industry were adopted, i.e., participants tasted the wine and were advised to use the swirl and spit technique during the testing and spit the contents of each glass into a spittoon. Swirling wine in the glass exposes it to a large surface area. This increases the wine's contact with air and intensifies its aromas. Spitting gives the opportunity to clear the palate. Participants were shown how to do this correctly. There was a two to four-minute pause between tasting each wine sample, where participants had the chance to consume water and have a cracker to clean their palate and write down their scores for that wine. Participants then completed the questionnaire questions. Consistent with good research practice to ensure avoidance of harm to participants, especially when employing a ruse as a necessary part of the experiment design, participants were debriefed about the fact that they only tasted two different types of wine instead of eight they were told they tasted. After they were debriefed, no harm, especially no harm arising from the use of the ruse, was observed. Rather, this caused some degree of amusement amongst the participants. Recall, as detailed in the design section, the present study would have been prohibitively difficult to conduct if eight different types of wine would have used (35, p. 342). 77 participants each provided 3 preference responses to 8 stimuli, yielding 1,848 data observations for analysis.

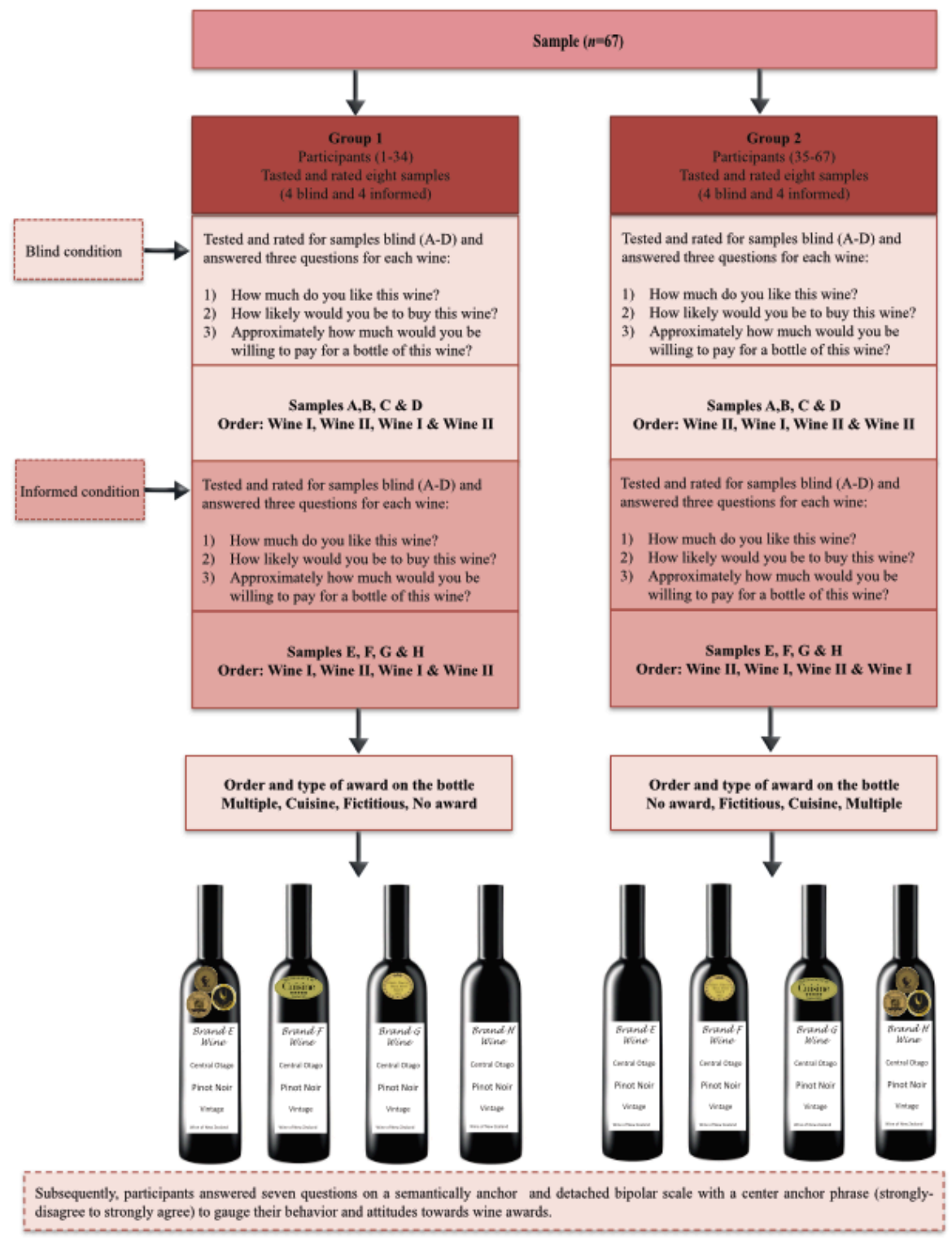

Figure 1. Outline of the Method used in this study. 


\subsection{Analysis of Data}

In the present study, each participant provided scores for four blind and four informed tastings for three different questions. The data was entered and restructured using IBM SPSS software so that participant scores were in consistent award level order, recognising that participants had received samples in different orders to mitigate ordering effects. Sensory fatigue of participants as the study progressed was tested by comparing the variances to the scores of each of the eight wine samples. There was no strong evidence that the variances differed across time.

Firstly, a factor analysis was performed to reduce seven questionnaire responses items into three relatively independent factors (see Table 3). Item 1 of the questionnaire was adapted from Lockshin et al. (36). The remaining items (items 2-7) were adapted from Orth and Krška (1). Items 5 and 7 were reversed. The loadings of each factor were then examined to profile and label each factor. Thus, factor scores for wine involvement, trust and distrust were produced.

Table 3. Components matrix for wine involvement (component 3), trust (component 1) and distrust (component 2) factors.

\begin{tabular}{|c|c|c|c|}
\hline & \multicolumn{3}{|c|}{ Component } \\
\hline & 1 & 2 & 3 \\
\hline $\begin{array}{l}\text { 1) I carefully consider which wine I } \\
\text { will buy before purchase. }\end{array}$ & .216 & .178 & .928 \\
\hline $\begin{array}{l}\text { 2) Wines that have received an award } \\
\text { have had their quality certified by } \\
\text { independent Experts. }\end{array}$ & .788 & -.165 & -.142 \\
\hline $\begin{array}{l}\text { 3) I trust the quality of a wine that has } \\
\text { received an award. }\end{array}$ & .786 & -.218 & -.072 \\
\hline $\begin{array}{l}\text { 4) I would not be prepared to pay more } \\
\text { for a wine that has received an award. }\end{array}$ & .450 & .561 & -.014 \\
\hline $\begin{array}{l}\text { 5) Wine awards do not help me to save } \\
\text { time when choosing wine. }\end{array}$ & .585 & .497 & -.262 \\
\hline $\begin{array}{l}\text { 6) Serving wine, which has received } \\
\text { an award, provides me confidence in } \\
\text { my wine choice. }\end{array}$ & .628 & -.511 & .197 \\
\hline $\begin{array}{l}\text { 7) I do not feel that a wine, which has } \\
\text { received an award, taste better. }\end{array}$ & .058 & .703 & .050 \\
\hline $\begin{array}{c}\text { Extraction Method: Principal } \\
\text { Component Analysis. } \\
\text { Influential items for each component } \\
\text { in bold. }\end{array}$ & & & \\
\hline
\end{tabular}

Then, a generalised linear model (37) was constructed to investigate the influences of various variables on the sensory responses, including, importantly, interactions between the questionnaire responses and the different experimental conditions. The model took the form:

$$
\begin{gathered}
Q_{m}=\beta_{0}+\sum_{2 \leq i \leq 2} \beta_{i} W T_{i}+\sum_{\substack{1 \leq i \leq 3 \\
n_{i}}} \beta_{i} F_{i}+\sum_{\substack{2 \leq i \leq 2 \\
1 \leq j \leq 4}} \beta_{i j} I L_{i} A L_{j} \\
+\sum_{\substack{2 \leq i \leq 2 \\
1 \leq j \leq 4}} \beta_{i j k} I L_{i} A L_{j} F_{k}+\sum_{\substack{2 \leq i \leq 2 \\
1 \leq k \leq 3 \\
1 \leq k \leq 3 \\
1 \leq l \leq 3 \\
k \neq 1}} \beta_{i j k l} I L_{i} A L_{j} F_{k} F_{l} \\
k \neq l
\end{gathered}
$$

where:

$Q_{m}$ is the question score, where m enumerates liking, likelihood to buy and willingness to pay; $W T_{1}$ and $W T_{2}$ are the types of wine used in the experiment; $I L_{i}$ are the so-called informed level variables: $I L_{2}$ is the informed condition, and $I L_{1}$ the blind condition; $A L_{j}$ are the award levels corresponding to multiple awards, Cuisine award, fictitious award and no award; and $F_{k}, F_{l}$ enumerate over the three factors identified from the factor analysis previously described. The data were modelled using the SAS GLIMMIX procedure.

\section{Results and Discussion}

A total of approximately $30 \%$ of the participants consumed wine a couple of times a week; approximately $20 \%$ consumed wine once a week and, approximately $50 \%$ occasionally. In the tests of sensory fatigue, the variances of the participants' tasting scores were of the same order of magnitude for each wine, and there was no discernible trend in the variances with respect to time (see Table 4 and 5). No evidence of sensory fatigue on the results was found.

\section{Results of the generalised linear model}

The results of the generalised linear model found that fifteen parameters had a significant effect on buy, like and pay at the $95 \%$ CL (see Table 6). The findings were as follows: HICs are less likely to buy $(\beta=-0.1807$ with $\mathrm{p}=0.0273)$, like $(\beta=-0.1677$ with $\mathrm{p}=0.0405)$ and pay $(\beta=-0.1309$ with $p=0.0069)$ for the wine used in the experiment. The results indicate that for HICs multiple awards had a negative effect on liking $(\beta=-0.3635$ with $\mathrm{p}=$ $0.0205)$. This finding confirms hypothesis $\mathrm{H}_{1 \mathrm{~b}}$. HICs were also found to be willing to pay less for a bottle with multiple awards, $\quad(\beta=-0.1087$ with $p=0.0026)$. This confirms hypothesis $\mathrm{H}_{1 \mathrm{c}}$. Note that no support was found for hypothesis $\mathrm{H}_{1 \mathrm{a}}$, which related to likelihood to buy a wine with multiple awards. It was found that consumers who trust awards are only willing to pay less for a bottle that has no award $(\beta=-0.09589$ with $p=0.0048)$.

Table 4. Check for sensory fatigue for group A

\begin{tabular}{ccc}
\hline & $\mathrm{N}$ & Variance \\
\hline $\begin{array}{c}\text { How likely would you be to } \\
\text { buy this wine A }\end{array}$ & 32 & 1.290 \\
$\begin{array}{c}\text { How likely would you be to } \\
\text { buy this wine B }\end{array}$ & 32 & 1.480 \\
$\begin{array}{c}\text { How likely would you be to } \\
\text { buy this wine C }\end{array}$ & 32 & 1.176 \\
$\begin{array}{c}\text { How likely would you be to } \\
\text { buy this wine D }\end{array}$ & 32 & 1.093 \\
$\begin{array}{c}\text { How likely would you be to } \\
\text { buy this wine } \mathrm{E}\end{array}$ & 32 & 1.362 \\
$\begin{array}{c}\text { How likely would you be to } \\
\text { buy this wine } \mathrm{F}\end{array}$ & 32 & .975 \\
$\begin{array}{c}\text { How likely would you be to } \\
\quad \text { buy this wine } \mathrm{G}\end{array}$ & 32 & 1.355 \\
$\begin{array}{c}\text { How likely would you be to } \\
\text { buy this wine } \mathrm{H}\end{array}$ & 32 & 1.512 \\
$\quad$ Valid N (listwise) & 32 & \\
\hline
\end{tabular}


Table 5. Check for sensory fatigue for group B

\begin{tabular}{|c|c|c|}
\hline & $\mathrm{N}$ & Variance \\
\hline $\begin{array}{l}\text { How likely would you be to } \\
\text { buy this wine A }\end{array}$ & 35 & 1.146 \\
\hline $\begin{array}{l}\text { How likely would you be to } \\
\text { buy this wine B }\end{array}$ & 35 & .946 \\
\hline $\begin{array}{l}\text { How likely would you be to } \\
\text { buy this wine } C\end{array}$ & 35 & 1.518 \\
\hline $\begin{array}{l}\text { How likely would you be to } \\
\text { buy this wine D }\end{array}$ & 35 & 2.020 \\
\hline $\begin{array}{l}\text { How likely would you be to } \\
\text { buy this wine E }\end{array}$ & 35 & 1.541 \\
\hline $\begin{array}{l}\text { How likely would you be to } \\
\text { buy this wine } F\end{array}$ & 35 & 2.022 \\
\hline $\begin{array}{l}\text { How likely would you be to } \\
\text { buy this wine } G\end{array}$ & 35 & 1.398 \\
\hline $\begin{array}{c}\text { How likely would you be to } \\
\text { buy this wine } H\end{array}$ & 35 & 1.608 \\
\hline Valid N (listwise) & 35 & \\
\hline
\end{tabular}

This result confirms the intuitive hypothesis $\mathrm{H}_{2 \mathrm{c}}$, although no support was found for hypotheses $\mathrm{H}_{2 \mathrm{a}}$ and $\mathrm{H}_{2 \mathrm{~b}}$ regarding liking and likelihood to buy. Findings show that HICs, who distrust awards, are less likely to like $(\beta=-0.4811$ with $p=$ $0.0043)$ and to buy $(\beta=-0.4006$ with $p=0.0174)$ a wine bottle with a fake award. This confirms hypothesis $\mathrm{H}_{3 \mathrm{a}}$ and $\mathrm{H}_{3 \mathrm{~b}}$. Similarly, HICs, who trust wine awards, are more likely to buy $(\beta=0.4022$ with $\mathrm{p}=0.0033)$, like $(\beta=0.3287$ with $\mathrm{p}=0.0162)$ and pay more $(\beta=0.07475$ with $\mathrm{p}=0.0119)$ for a wine bottle with a fake award. This finding supports hypotheses $\mathrm{H}_{3 \mathrm{a}}, \mathrm{H}_{3 \mathrm{~b}}$ and $\mathrm{H}_{3 \mathrm{c}}$. The generalised linear model shows significant results suggesting that $\mathrm{HICs}$, who distrust awards, are only willing to pay less $(\beta=-0.1378$ with $\mathrm{p}=0.0005$ ) for a wine bottle with multiple awards. This confirms hypothesis $\mathrm{H}_{4 \mathrm{c}}$. Similarly, HICs, who trust wine awards, are more likely to buy ( $\beta=0.3847$ with $p=0.0049$ ), like $(\beta=0.3055$ with $p=0.0254)$ and pay more $(\beta=0.08504$ with $\mathrm{p}=0.0044$ ) for a wine bottle with multiple awards. These results support hypotheses $\mathrm{H}_{4 \mathrm{a}}, \mathrm{H}_{4 \mathrm{~b}}$ and $\mathrm{H}_{4 \mathrm{c}}$. Table 6 shows the statistically significant results of the generalized linear model described in materials and methods section, ignoring the intercept. The subscript inv denotes involvement, tr denotes trust, dis denotes distrust, mult denotes multiple awards, none denotes no award and fake denotes the fake award.

\section{Conclusions, Limitations and Future Research}

In this paper, we propose that, when it comes to awards or medals, on wine labels, less is definitely more. Our research investigates the effectiveness of multiple awards on wine labels across consumer segments differentiated by levels of category involvement, wine award trust and distrust. "Look at me! Look at me! Look how many awards I have won!" may not be the best 'look' (sic).

In order to show the effectiveness of awards on wine labels for different consumer segments five hypotheses were tested. These were formulated using the results by Neuninger (12) and inferences drawn from the literature review. As shown in Table 7 some of these hypotheses were confirmed and others were not. We also compare our findings with what others found where available.

Table 6. Parameter Estimates for Generalised Linear Model.

\begin{tabular}{ccccccc}
\hline Effect & pref & $\beta$ & Standard Error & DF & $t$ Value & Pr $>|t|$ \\
\hline$F_{\text {inv }}$ & buy & -0.1807 & 0.08153 & 354.7 & -2.22 & 0.0273 \\
$F_{\text {inv }}$ & like & -0.1677 & 0.08153 & 354.7 & -2.06 & 0.0405 \\
$F_{\text {inv }}$ & pay & -0.1309 & 0.04438 & 24.37 & -2.95 & 0.0069 \\
$\mathrm{~F}_{\text {inv }} \mathrm{IL}_{2} \mathrm{AL}_{\text {mult }}$ & like & -0.3635 & 0.1566 & 946.4 & -2.32 & 0.0205 \\
$\mathrm{~F}_{\text {inv }} \mathrm{IL}_{2} \mathrm{AL}_{\text {mult }}$ & pay & -0.1087 & 0.03603 & 1461 & -3.02 & 0.0026 \\
$\mathrm{~F}_{\text {trI }} \mathrm{IL}_{2} \mathrm{AL}_{\text {none }}$ & pay & -0.09589 & 0.03398 & 1461 & -2.82 & 0.0048 \\
$\mathrm{~F}_{\text {inv }} \mathrm{F}_{\text {dis }} \mathrm{IL}_{2} \mathrm{AL}_{\text {fake }}$ & buy & -0.4006 & 0.1681 & 946.4 & -2.38 & 0.0174 \\
$\mathrm{~F}_{\text {inv }} \mathrm{F}_{\text {dis }} \mathrm{IL}_{2} \mathrm{AL}_{\text {fake }}$ & like & -0.4811 & 0.1681 & 946.4 & -2.86 & 0.0043 \\
$\mathrm{~F}_{\text {inv }} \mathrm{F}_{\text {dis }} \mathrm{IL}_{2} \mathrm{AL}_{\text {mult }}$ & pay & -0.1378 & 0.03950 & 1461 & -3.49 & 0.0005 \\
\hline
\end{tabular}


Table 7. Confirmed/unconfirmed Hypotheses in this research.

\begin{tabular}{|c|c|c|c|c|}
\hline $\begin{array}{l}\text { Motivating } \\
\text { literature }\end{array}$ & Our research questions & Our Hypotheses & Our findings & Others found... \\
\hline $\begin{array}{l}\text { Lockshin et al. (15) } \\
\text { shows that gold } \\
\text { awards had a high } \\
\text { effect on LICs in } \\
\text { particular. }\end{array}$ & $\begin{array}{l}\text { As an extension to their } \\
\text { study, we wish to } \\
\text { investigate if multiple (real } \\
\text { gold) awards will also have } \\
\text { the same effect on LICs. }\end{array}$ & $\begin{array}{l}\mathrm{H}_{1} \text { : For wines with } \\
\text { multiple (real gold) } \\
\text { awards, LICs are more } \\
\text { likely to: } \\
\mathrm{H}_{1 \mathrm{a}} \text { : buy a wine. } \\
\mathrm{H}_{1 \mathrm{~b}} \text { : like a wine. } \\
\mathrm{H}_{1 \mathrm{c}} \text { : pay more for a wine. }\end{array}$ & $\begin{array}{l}\text { Note that no support was } \\
\text { found for hypothesis } \mathrm{H}_{1 \mathrm{a}} \text {. } \\
\mathrm{H}_{1 \mathrm{~b}} \text { : for HICs multiple } \\
\text { awards had a negative effect } \\
\text { on liking. This confirms } \mathrm{H}_{1 \mathrm{~b}} \text {. } \\
\text { HICs were also found to be } \\
\text { willing to pay less for a bottle } \\
\text { with multiple awards. This } \\
\text { confirms hypothesis } \mathrm{H}_{1 \mathrm{c}} \text {. }\end{array}$ & $\begin{array}{l}\text { that respondents preferred } \\
\text { awarded wines over bottles } \\
\text { that display no award. Within a } \\
\text { specific exhibition level } \\
\text { (regional, national, } \\
\text { international), gold medals } \\
\text { were preferred over silver or } \\
\text { bronze medals. Findings } \\
\text { support previous assumptions } \\
\text { that wine awards can be used } \\
\text { to target less experienced and } \\
\text { convenience buyers (38). } \\
\text { Awards were of low influence } \\
\text { in wine purchasing decisions } \\
\text { (39). }\end{array}$ \\
\hline $\begin{array}{l}\text { No motivating } \\
\text { literature }\end{array}$ & $\begin{array}{l}\text { What is the interaction } \\
\text { amongst trust, the absence } \\
\text { of wine awards and } \\
\text { consumer preference? }\end{array}$ & $\begin{array}{l}\mathrm{H}_{2} \text { : Consumers who trust } \\
\text { awards are less likely to: } \\
\mathrm{H}_{2 \mathrm{a}} \text { : buy a wine with no } \\
\text { award. } \\
\mathrm{H}_{2 \mathrm{~b}} \text { : like a wine with no } \\
\text { award. } \\
\mathrm{H}_{2 \mathrm{c}} \text { : pay more for a wine } \\
\text { with no award. }\end{array}$ & $\begin{array}{l}\text { Our results confirm the } \\
\text { intuitive hypothesis } \mathrm{H}_{2 \mathrm{c}} \text {, } \\
\text { although no support was } \\
\text { found for hypotheses } \mathrm{H}_{2 \mathrm{a}} \text { and } \\
\mathrm{H}_{2 \mathrm{~b}} \text { regarding liking and } \\
\text { likelihood to buy. }\end{array}$ & $\begin{array}{l}\text { Nothing was found in the } \\
\text { existing literature. }\end{array}$ \\
\hline $\begin{array}{l}\text { Based on the findings } \\
\text { by Neuninger }(12, \mathrm{p} \text {. } \\
89) \text {, consumers who } \\
\text { are highly involved } \\
\text { with wine only trust } \\
\text { a few prestigious } \\
\text { awards. }\end{array}$ & $\begin{array}{l}\text { Is there an interaction } \\
\text { between involvement and } \\
\text { distrust with regard to fake } \\
\text { awards? }\end{array}$ & $\begin{array}{l}\mathrm{H}_{3} \text { : Consumers who } \\
\text { distrust awards and who } \\
\text { are highly involved with } \\
\text { wine are less likely to: } \\
\mathrm{H}_{3 \mathrm{a}} \text { : buy a wine with a } \\
\text { fake award. } \\
\mathrm{H}_{3 \mathrm{~b}} \text { : like a wine with a } \\
\text { fake award. } \\
\mathrm{H}_{3 \mathrm{c}} \text { : pay more for a wine } \\
\text { with a fake award. }\end{array}$ & $\begin{array}{l}\text { Findings show that HICs, } \\
\text { who distrust awards, are less } \\
\text { likely to like and to buy a } \\
\text { wine bottle with a fake } \\
\text { award. This confirms } \\
\text { hypotheses } \mathrm{H}_{3 \mathrm{a}} \text { and } \mathrm{H}_{3 \mathrm{~b}} \text {. } \mathrm{H}_{3 \mathrm{c}} \text { is } \\
\text { not supported. }\end{array}$ & $\begin{array}{l}\text { The more sophisticated a } \\
\text { consumer is, the less they pay } \\
\text { attention towards awards. } \\
\text { Their attitudes toward awards } \\
\text { wine awards are more negative } \\
\text { than that of lesser-informed } \\
\text { consumers }(10) .\end{array}$ \\
\hline $\begin{array}{l}\text { Based on the findings } \\
\text { by Neuninger (12, p. } \\
89) \text {, consumers who } \\
\text { are highly involved } \\
\text { with wine only trust } \\
\text { a few prestigious } \\
\text { awards. }\end{array}$ & $\begin{array}{l}\text { Is there an interaction } \\
\text { between involvement and } \\
\text { distrust with regard to } \\
\text { multiple awards? }\end{array}$ & $\begin{array}{l}\mathrm{H}_{4} \text { : Consumers who } \\
\text { distrust awards and who } \\
\text { are highly involved with } \\
\text { wine are less likely to: } \\
\mathrm{H}_{4 \mathrm{a}}: \text { buy a wine with } \\
\text { multiple awards. } \\
\mathrm{H}_{4 \mathrm{~b}} \text { : like a wine with } \\
\text { multiple awards. } \\
\mathrm{H}_{4 \mathrm{c}}: \text { pay more for a wine } \\
\text { with multiple awards. }\end{array}$ & $\begin{array}{l}\text { HICs, who distrust awards, } \\
\text { are only willing to pay less } \\
\text { for a wine bottle with } \\
\text { multiple awards. HICs, who } \\
\text { trust wine awards, are more } \\
\text { likely to buy, like and pay } \\
\text { more with for a wine bottle } \\
\text { with multiple awards. These } \\
\text { results support hypotheses } \\
\mathrm{H}_{4 \mathrm{a}}, \mathrm{H}_{4 \mathrm{~b}} \text { and } \mathrm{H}_{4 \mathrm{c}} \text {. }\end{array}$ & $\begin{array}{l}\text { Nothing was found in the } \\
\text { existing literature. }\end{array}$ \\
\hline $\begin{array}{l}\text { Motivated by the } \\
\text { results of the study by } \\
\text { Neuninger (12), it is } \\
\text { therefore expected } \\
\text { that this consumer } \\
\text { segment will be not } \\
\text { well informed about } \\
\text { the topic of wine } \\
\text { awards, particularly } \\
\text { compared to the } \\
\text { knowledge of HICs } \\
\text { and ECs. }\end{array}$ & $\begin{array}{l}\text { How influential are wine } \\
\text { awards on the NWD's } \\
\text { segment? }\end{array}$ & $\begin{array}{l}\mathrm{H}_{5}: \mathrm{NWDs} \text { have less } \\
\text { interest in wine awards } \\
\text { than other wine drinking } \\
\text { segments. }\end{array}$ & $\begin{array}{l}\text { The findings show no } \\
\text { evidence of any interest in } \\
\text { wine awards by the NWD's } \\
\text { segment. }\end{array}$ & $\begin{array}{l}\text { Found that participants in their } \\
\text { study do not particularly trust } \\
\text { wine awards and wine } \\
\text { competitions (39). }\end{array}$ \\
\hline
\end{tabular}

All hypotheses had at least one part supported. The other parts were not supported having poor (high) parameter estimate $\mathrm{p}$-values at the $95 \%$ confidence level in the results relating to the relevant variables in the generalised linear model. It is suspected that despite the relatively large number of observations analysed, $(1,848)$, that if this experiment had been performed with a larger number of sampling units ( $>$ the 77 participants in this study), we may have found further support for some of these hypotheses at the $95 \%$ confidence level.

Since there are no statistical-theory-based a-priori formulae for sample size and power for generalised linear models, and post hoc tests for these statistics cannot be done in our study as the bootstrap requires a minimum of 100 sampling units (as opposed to observations) to test sample size adequacy for inferences and even more importantly, we have used a convenience sample and so, we cannot claim generalisability of these results (40). Thus, we encourage 
other researchers who attempt replication to employ at least 100 usable participants and use some sort of representative sampling method. Notwithstanding these sampling limitations, our inferences are based on adequate data and the most appropriate statistical model frameworks, and so should not be discounted.

The results have implications for the wine industry. Firstly, it was shown that trust in wine awards generally increased the amount willing to pay for a wine with an award by consumers. Therefore it is recommended that efforts should be taken by the wine industry to ensure awards are credible and trustworthy for consumers. Moreover, the effectiveness of wine awards can by optimised by considering the types and number of awards to place on a wine bottle targeted at different consumer segments. In particular, wines aimed at HICs (for example premium-priced, high-quality wine) should not be displayed with an award that has poor recognition among wine consumers. Doing so will reduce the perceived liking of a wine within this segment (in particular, those who distrust awards), as well as reducing their likelihood to buy and the price willing to pay. For the same reasons, it is recommended that premium wines targeted at HICs should not be displayed with multiple awards.

The current experiment was performed predominantly on the NWDs involvement group due to the nature of the recruitment process. However, within the segment involvement varied and the differences were reviled by the involvement factor of the questionnaire. The analysis in Neuninger (12) indicates that similar experiments with different demographics, e.g., different involvement groups, might reveal interesting differences in sensory results between the groups. Such differences were not strongly supported by the results of the generalised linear model, but stronger results may be supported when a larger and more balanced sample of the population is tested.

\section{Acknowledgements}

We would like to thank the University of Otago, Applied Science Program, for awarding the Home Science/Todhunter/ Carpenter Scholarship to conduct this research.

\section{REFERENCES}

[1] Orth U, Krška P. Quality signals in wine marketing: The role of exhibition awards. International Food and Agribusiness 2002;4(4):385- 97.

[2] Eastern Institute of Technology. New Zealand wine competitions New Zealand, Hawke's Bay2011 [cited 2014 February 6]. Available from: http://www.eit.ac.nz/wp-conten t/uploads/2010/10/AnnualRep2011_Web1.pdf.
[3] Jackson B. The Marlborough wine show, entry criteria 2016 2016 [cited 201626 September ]. Available from: http://www.wine-marlborough.co.nz/wp-content/uploads/20 16/08/MWS-Entry-Criteria-2016.pdf.

[4] Pendock N. Wine competitions: useful or a money-making scam? 2016 [cited 2016 September 28]. Available from: http://neilpendock.com/wine-competitions-useful-or-a-mone y-making-scam/.

[5] Charters S. The contemporary wine consumer: The social and cultural context of a drink Wine \& Society: Elsevier Ltd.; 2006. p. 205-26.

[6] Pendock N. Wine competitions: a cheaper and more effective alternative 2009 [cited 2016 September 28]. Available from: http://neilpendock.com/wine-competitions-a-cheaper-and-m ore-effective-alternative/.

[7] Air New Zealand. Air New Zealand wine awards 2015 [cited 2015 January 8]. Available from: http://www.airnewzealand wineawards.co.nz.

[8] Schiefer J, Fischer C. The gap between wine expert ratings and consumer preferences International Journal of Wine Business Research. 2008;20(4):335- 51.

[9] Quandt R. Measurement and inference in wine tasting. Journal of Wine Economics. 2006;1(1):7-30.

[10] Herbst F, von Arnim C. The role and influence of wine awards as perceived by the South African wine consumers. Acta Commercii. 2009;9(1):90-101.

[11] Brady A. Pinot Noir Central Penguin Groups; 2010.

[12] Neuninger R. The Role of Awards on Consumer Decision-Making: A Study of Wine Awards. Dunedin, New Zealand Univerity of Otago; 2014.

[13] Mueller S, Osidacz P, Francis IL, Lockshin L. Combining discrete choice and informed sensory testing in a two-stage process: Can it predict wine market share? Food Quality and Preference. 2010;21(7):741-54.

[14] Mather DW, Knight JG, Insch A, Holdsworth DK, Ermen DF, Breitbarth T. Social Stigma and Consumer Benefits Trade-Offs in Adoption of Genetically Modified Foods. Science Communication. 2012;34(4):487-519.

[15] Lockshin L, Jarvis W, d'Hauteville F, Perrouty J. Using simulations from discrete choice experiments to measure consumer sensitivity to brand, region, price, and awards in wine choice. Food Quality and Preference. 2006;17(34):166- 78.

[16] Johnson T, Bastian S. A preliminary study of the relationship between Australian wine consumers' wine expertise and their wine purchasing and consumption behaviour. Australian Journal of Grape and Wine Research. 2007;13(3):186-97.

[17] Lockshin L, Mueller S, Louviere J, Francis L, Osidacz P. Development of a new method to measure how consumers choose wine. Australian \& New Zealand Wine Industry Journal. 2009;24(2):35.

[18] Jaeger S, Danaher P, Brodie R. Wine purchase decisions and consumption behaviours: Insights from a probability sample drawn in Auckland, New Zealand. Food Quality and Preference. 2009;20(4):312-9.

[19] Chrysochou P, Krystallis A, Mocanu A, Lewis R. Generation 
Y preferences for wine: an exploratory study of the US market applying the best-worst scaling. British Food Journal. 2012;114(4):516-28.

[20] Corsi A, Mueller S, Lockshin L. Let's See What They Have... What Consumers Look For in a Restaurant Wine List. Cornell Hospitality Quarterly. 2012;53(2):110-21.

[21] Chrea C, Melo L, Evans G, Forde C, Delahunty C, Cox DN. An investigation using three approaches to understand the influence of extrinsic product cues on consumer behaviour: an example of Australian wines. Journal of Sensory Studies. 2011;26(1):13-24.

[22] Zaichkowsky J. Measuring the involvement construct. Journal of Consumer Research. 1985;12(3):341-52.

[23] Charters S, Pettigrew S. The dimensions of wine quality. Food Quality and Preference. 2007;18(7):997-1007.

[24] Lockshin L, Spawton T. Using involvement and brand equity to develop a wine tourism strategy. International Journal of Wine Marketing. 2001;13(1):72-81

[25] Lockshin L, Hall J. Consumer purchasing behaviour for wine: what we know and where we are going: University of South Australia, Wine Marketing Research Group; 2003.

[26] Keown C, Casey M. Purchasing behaviour in the Northern Ireland wine market. British Food Journal. 1995;97(1):17-20.

[27] Spawton T. Marketing planning for wine. European Journal of Marketing. 1991;25(3):6-48.

[28] Silayoi P, Speece M. Packaging and purchase decisions: An exploratory study on the impact of involvement level and time pressure. British food journal. 2004;106(8):607-28.

[29] Lockshin L, Halstead L. A comparison of Australian and Canadian wine buyers using discrete choice analysis. International wine marketing symposium; 8-9 of July; Rohnert Park, Sonoma Country, USA2005.

[30] Schamel G. A hedonic pricing model for German wine Agrarwirtschaft. 2003;52(5):247-54
[31] Verbeke W. Consumer acceptance of functional foods: socio-demographic, cognitive and attitudinal determinants. Food quality and preference. 2005;16(1):45-57.

[32] Zalesky C. Measurement and Scaling: Noncomparative Scaling Techniques In: Malhotra NK, editor. Marketing Research: An Applied Orientation. 5th ed: Pearson Prentice Hall 2007. p. 274- 5.

[33] MacFie H, Bratchchell N, Greenhoff K, Vallis L. Designs to balance the effect of order of presentation and first-order carry-over effects in Hall tests. Journal of Sensory Studies. 1989;4(2):129-48.

[34] Lesschaeve I, Noble A. Sensory analysis of wine In: Reynolds AG, editor. Managing wine quality. North America: Woodhead Publishing Limited and CRC Press LLC; 2010. p. 188-211.

[35] Cooper D. A Note on Deception in Economic Experiments. Journal of Wine Economics. 2014;9(2):111-4.

[36] Lockshin L, Quester P, Spawton T. Segmentation by Involvement or Nationality for Global Retailing: A Cross-national Comparative Study of Wine Shopping Behaviours. Journal of Wine Research. 2001;12(3):223-36.

[37] McCullagh P, Nelder J. Generalized Linear Model Second ed. USA: Chapman \& Hall/CRC; 1989.

[38] Orth U. Research note: Targeting the un-experienced and the convenience shopper. International Journal of Wine Marketing. 2002;14(3):80-2.

[39] Yu Y, Sun H, Goodman S, Chen S, Ma H. Chinese choices: a survey of wine consumers in Beijing. International Journal of Wine Business Research. 2009;21(2):155-68.

[40] Castelloe JM, O'Brien RG, editors. Power and sample size determination for linear models. Proceedings of the Twenty-Sixth Annual SAS Users Group International Conference; 2001. 